\title{
Challenges and opportunities for promoting functional foods in e-commerce
}

\author{
Liudmila Nilova ${ }^{1}$, and Svetlana Malyutenkova ${ }^{1, *}$ \\ ${ }^{1}$ Peter the Great St. Petersburg Polytechnic University, 195220, 29 Polytechnic st.,St. Petersburg, \\ Russia
}

\begin{abstract}
In order to promote functional foods, the consumer should be informed about the health benefits that can be done through e-commerce. A survey of consumers living in St. Petersburg showed that only $18 \%$ of respondents carry out the order of food products via the Internet with the immediate prospect of increasing their number by $19 \%$. An analysis of the websites of online stores, the assortment of food products on the example of bread and bakery products and the terms for their delivery and return revealed the main reasons for restricting online purchases of food products: the absence of significant differences in the assortment between online stores and retail outlets; lack of confidence in the delivery of quality and fresh products; the difficulty of returning products. An additional restriction on the purchase of functional foods is the lack of information about their health benefits, both on the websites of online stores and in the labelling. It is proposed to clearly position functional products on the websites of online stores in the bread and bakery segment, providing them with additional information resources about health benefits; create an additional service "Baking to order" with special delivery terms.
\end{abstract}

\section{Introduction}

In today's digital economy has been actively developing e-commerce, as one of the channels of promotion of goods in the consumer market. Currently, e-commerce is presented in different formats. Large retailers carry out sales in the global and national markets, among which "Aliexpress" and "Amazon" are leaders in terms of sales. In addition, domestic retail channels and marketplaces are developing in domestic markets [1, 2].

E-commerce is seen as a quantum leap in the development of trade, providing the consumer with a reduction in time to make a purchase, and the seller with a reduction in the cost of business processes. Consumer awareness of the range of goods, its properties and purpose is presented on the seller's websites, in social networks, can be carried out through applications or by sending catalogues to e-mail [3-5].The quality and reliability of the information provided on the site, regardless of the purchase frequency of goods in ecommerce, is crucial for the consumer [6]. The possible relationship between a seller and a manufacturer of goods will allow a consumer to obtain additional information about goods,

* Corresponding author: malutesha66@mail.ru 
as well as the use of QR bar code in the marking [7-9]. Internet technologies can help retail target certain categories of consumers, and consumers make more informed decisions about the choice and purchase of goods [10].

E-commerce in non-food items has a certain experience, where the main factors for a consumer are trust in a manufacturer and site providing the service, availability of show rooms [11]. Modern Internet technologies allow a consumer to easily navigate on a site thanks to convenient navigation or intelligent agent, participate in group Internet purchases, forming additional benefits [12]. Block chain technology allows retailers to manage supply chains, prevent product falsification [13].Further development of e-commerce is attributed to the expansion of sales of food products, especially everyday demand.

The problems of developing e-commerce in food products may be related to consumer mistrust of their quality and security. To prevent electronic sales of dangerous food products, special software has been developed with automatic recognition and a multi-stage process of filtering data from websites and a tool of image analysis and monitoring [14]. However, dangerous and falsified foodstuffs when sold on-line can get to the consumer. Thus, in China, cereal-based food products (flour, cereal, bread, and bakery products), in which the content of deoxynivalenol (mycotoxin) exceeded the legally established permissible norms by 1.7-12.7 times, were registered in online sales [15]. In EU countries, consumers of e-commerce may face food products falsification of protected denomination origin (PDO). According to an inspection of PDO products sold in e-commerce about $71.4 \%$ of PDO dairy products and $46.1 \%$ of PDO meat product samples studied included species replacements, and 55\% had incorrect labelling [16]. Often, the consumer associates his choice with taste, tactile sensations, and freshness of food products, which can have a negative impact on the sale of bread and bakery products through online trading [17]. From this point of view, the shelf life of food products, the delivery time, the ability to track the quality upon receipt and the conditions for their return become important for the consumer. To promote a new assortment of food products, which include functional food products, the information about the product and its properties plays the important role [18, 19]. In this context, the online trade in bread and bakery products has great potential. The purpose of the work is to study the challenges and opportunities for promotion of functional foods in ecommerce in St. Petersburg on the example of bakery products.

\section{Methods}

Empirical studies were conducted using the method of content-analysis of the websites of online retailers Auchan, O'Key, PRISMA, the wholesale club RYADY, Azbuka vkusa, the website of the partner company for the delivery of goods from hypermarkets (such as Lenta, Perekrestok, Carousel, located in St. Petersburg), LLC AIGUDS SISTEMS (iGooods.ru), TESCO and Walmart.

The online survey was conducted using Google service. The sample size was 300 people, of which $45 \%$ were men and $55 \%$ were women. The criterions for the selection of respondents were the age limit of 18 years and residence in St. Petersburg.

\section{Results and Discussion}

For consumers in St. Petersburg, the on-line ordering service for food products and related products is available for large hypermarkets such as Auchan, O'Key, PRISMA, etc. But not all major retailers have their own websites and delivery service. Many of them, such as Lenta and Carousel, use a single delivery service through the partner firm iGooods Systems (iGooods.ru). The advantage for consumers of this service is the ability to make choices 
when ordering online from a wide retail range with the maximum availability of goods in stock. In the absence of goods for sale, the system automatically offers to buy the necessary assortment of goods in another retail store that has a web site with its own assortment of goods.

Not all consumers of St. Petersburg use the service of purchasing food products through online trading. Only $18 \%$ of the surveyed Internet users purchase food products in online stores (Figure 1), the main age of which is from 30 to 40 years. On average, in Russia, the share of consumers making food purchases via the Internet is $4 \%$ higher (Grewal, 2017).

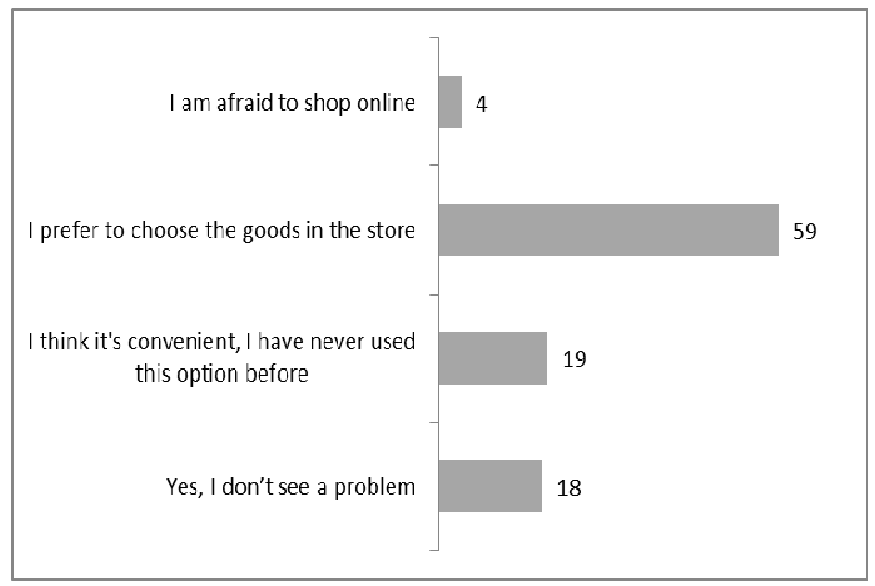

Fig. 1. Consumer attitude towards purchasing functional products through online services in St. Petersburg, \% of respondents.

Potential consumers of online purchases may be $19.5 \%$ of respondents who have not made them before. But most respondents prefer to choose food products at retail outlets, which are associated with the development of network trading, which often acquires the status of convenience store.

The main reason for using the on-line service for ordering food products is a high rhythm of life and employment at work. However, the following were indicated in the free answers about the reasons for the refusal: I do not want to overpay for delivery; lack of confidence in the quality and freshness of food; I prefer to pay for goods after a visual assessment of quality; not ready to spend time returning; food is needed for dinner and if the quality is not satisfactory, then you will remain hungry. Thus, the main reason for refusing to purchase food products over the Internet is related to a lack of confidence in the quality of ordered goods, especially perishable ones. The reasons for the purchase of functional foods are not only health benefits, but also high taste, which was preferred by most consumers who purchase (Figure 2).

In the absence of information on the health benefits, consumers consider functional foods as products of a new assortment. They are often not ready to buy them because of the high price. The advantage of functional foods as a health benefit in labelling is largely absent due to the inability to place it due to the small size of the packaging. Only 8 consumers out of 300 respondents remained indifferent to functional food products.

When asked what food products can be attributed to functional products, consumers clearly called sour-milk drinks, primarily yoghurts, which they associated with advertising in the media. But only $10 \%$ of the respondents agree to use the online service for the purchase of sour-milk drinks because of the uncertainty of delivering a quality product. Functional bread and bakery products were attributed to consumers only grain bread, despite the trends in the development and production of bread and bakery products with natural antioxidants from plant materials [21, 22]. The production trend in Russia of bread 
enriched with vitamin and mineral complexes in St. Petersburg was not widespread, so only $15 \%$ of consumers purchased or were ready to purchase it. Consumers are not interested in online sales of bread, since it can be easily purchased at any convenience store with a guarantee of the choice of high-quality goods, and it may be absent (Auchan) in online stores or offered in a limited assortment. Therefore, one way to attract consumers to online purchases of bread and bakery products can be an assortment of products with new properties.

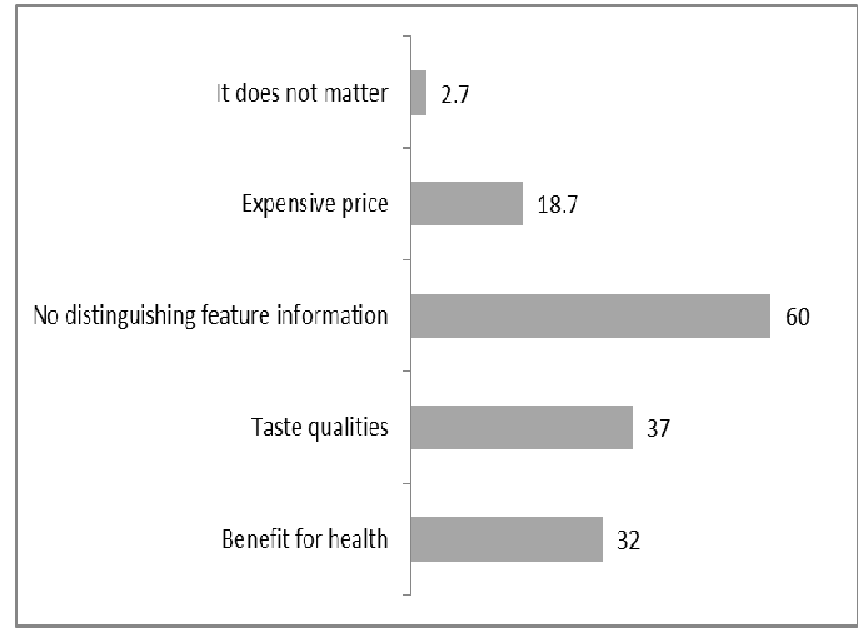

Fig. 2. Consumer attitudes towards purchasing functional products, $\%$ of respondents.

The analysis of the assortment of bread and bakery products in online stores is presented in table 1. Compared to retail stores Walmart and TESCO, online stores in St. Petersburg offer fewer types of bread by product subgroups. Moreover, all product subgroups "Bread" on the Amazon market are present. According to the total number of items, the top five included online stores: Walmart $>$ TESCO $>$ Tape $>$ Prisma $>$ METRO. In the assortment of foreign online stores, in contrast to Russian, the proportion of bread with additives is higher, but the assortment of grain bread can be comparable depending on the type of online store. Toast bread is popular in the USA and Europe, the assortment of which in Russia is very narrow - 1-13 items. But this is offset by a wide range of rye-wheat and wheat flour bread and wheat flour loaves, which Russians can use to replace toast bread.

A comparison was made of the assortment of bread in online trading and in such retail hypermarkets as Perekrestok and O'Key (Table 2).

The differences between the online assortment and the assortment of bread in retail are not so significant. In Perekrestok the online assortment predominates in online procurement, while in $\mathrm{O}^{\prime} \mathrm{Key}$, on the contrary, there is more bread assortment in retail. The most significant difference is in the sales of bread of our own bakeries. When ordering online at Perekrestok, the choice of bread of our own production is less than 2 times less, and at O'Key it will not be possible to order them at all. The reason is the rapid decline in the quality and freshness of the bread of the bakeries of the hypermarket, and upon delivery a few hours after baking, the consumer may demand the return of goods. This may cause a refusal to purchase the entire set of food products over the Internet. The delivery terms of the online ordering of a set of food products differ in delivery time and its cost, and may also depend on the weight or dimensions of the complete set (Table 3). Free delivery is possible, but the order amount must be substantial from 2700 rubles and higher depending on retail. When ordering through Igoods free delivery is not available. 
Table 1. Comparative analysis of the assortment of bread sold in retail and online trading.

\begin{tabular}{|c|c|c|c|c|c|c|c|c|c|c|}
\hline \multirow[t]{2}{*}{ Group } & \multicolumn{8}{|c|}{ Russian Federation, St.Petersburg } & \multirow[b]{2}{*}{$\begin{array}{l}\text { Walmart } \\
\text { Grocery }\end{array}$} & \multirow[b]{2}{*}{$\begin{array}{c}\text { TESCO } \\
\text { (Great } \\
\text { Britain) } \\
\end{array}$} \\
\hline & Perekrestok & O'Key & Prisma & METRO & Lenta & Carousel & RYADY & $\begin{array}{c}\text { Azbuka } \\
\text { vkusa }\end{array}$ & & \\
\hline Total items & 76 & 71 & 133 & 117 & 176 & 91 & 23 & 117 & 501 & 306 \\
\hline Total brands & 9 & 11 & 21 & 22 & 25 & 19 & 8 & 35 & 41 & 58 \\
\hline $\begin{array}{l}\text { Total bread } \\
\text { groups }\end{array}$ & 7 & 6 & 9 & 9 & 11 & 9 & 5 & 13 & 8 & 26 \\
\hline \multicolumn{11}{|l|}{ Including: } \\
\hline $\begin{array}{l}\text { from wheat } \\
\text { flour }\end{array}$ & 39 & 30 & 55 & 43 & 73 & 41 & 11 & 15 & 72 & 51 \\
\hline $\begin{array}{l}\text { from rye and } \\
\text { a mixture of } \\
\text { rye and } \\
\text { wheat flour }\end{array}$ & 15 & 16 & 52 & 33 & 64 & 34 & 7 & 35 & 97 & 63 \\
\hline $\begin{array}{l}\text { with cereal } \\
\text { additives }\end{array}$ & 11 & 12 & 16 & 15 & 17 & 12 & 2 & 30 & 31 & 24 \\
\hline $\begin{array}{l}\text { with other } \\
\text { additives }\end{array}$ & 7 & 5 & 10 & 26 & 22 & 4 & 3 & 37 & 301 & 168 \\
\hline toast bread & 1 & 13 & 4 & 4 & 3 & 1 & 5 & 2 & 218 & 109 \\
\hline
\end{tabular}

Table 2. Comparative analysis of the assortment of bread sold in retail and through online sales.

\begin{tabular}{|l|c|c|c|c|}
\hline \multirow{2}{*}{ Group assortment } & \multicolumn{2}{|c|}{ Perekrestok } & \multicolumn{2}{c|}{ O'Key } \\
\cline { 2 - 5 } & retail & online sale & retail & online sale \\
\hline Total items & 63 & 76 & 31 & - \\
\hline $\begin{array}{l}\text { Including own } \\
\text { production }\end{array}$ & 18 & 8 & 37 & 11 \\
\hline Total brands & 12 & 9 & 3 & 6 \\
\hline Total bread groups & 7 & 5 & 57 & 30 \\
\hline Including: & 33 & 39 & 28 & 16 \\
\hline from wheat flour & 13 & 15 & 11 & 12 \\
\hline $\begin{array}{l}\text { from rye and a mixture } \\
\text { of rye and wheat flour }\end{array}$ & 14 & 11 & 22 & 5 \\
\hline with cereal additives & 3 & 7 & 7 & 13 \\
\hline with other additives & - & 1 & & \\
\hline toast bread & \multicolumn{5}{|l}{} \\
\hline
\end{tabular}

Table 3. On-line delivery terms for retailers in different countries.

\begin{tabular}{|l|l|l|l|}
\hline Retailers & Shipping cost & $\begin{array}{l}\text { Free shipping on } \\
\text { purchase amount }\end{array}$ & Minimum delivery time \\
\hline $\begin{array}{l}\text { Perekrestok } \\
\text { Russia) }\end{array}$ & $\begin{array}{l}\text { 99-149 rubles, depending } \\
\text { on the delivery time . In the } \\
\text { same day }\end{array}$ & 4000 rubles & On the same day \\
\hline O'Key (Russia) & 249 rubles & 2700 rubles & On the next day \\
\hline Auchan (Russia) & $\begin{array}{l}\text { depends on the size of the } \\
\text { order }\end{array}$ & - & $\begin{array}{l}\text { On the same day when } \\
\text { ordering before } 12.00\end{array}$ \\
\hline RYADY (Russia) & 199 rubles & 3000 rubles & $\begin{array}{l}\text { wh minutes after ordering } \\
12.00\end{array}$ \\
\hline Igooods.ru (Russia) & $\begin{array}{l}249-499 \text { rubles, depending } \\
\text { on the weight }\end{array}$ & $\$ 35$ & $\begin{array}{l}\text { Free 2-Day Shipping for } \\
\text { goods with a special image }\end{array}$ \\
\hline Walmart Grocery & $\begin{array}{l}\$ 9.95 \\
\text { deliveries any day, including } \\
\text { same-day }\end{array}$ \\
\hline $\begin{array}{l}\text { TESCO } \\
\text { (Great Britain) }\end{array}$ & $\begin{array}{l}\text { From } £ 2+£ 4 \text { if your spend } \\
\text { is below } £ 40\end{array}$ & $£ 40$ &
\end{tabular}

Walmart has introduced a subscription-based, unlimited-delivery option for its online grocery service. Dubbed "Delivery Unlimited," the new service enables Walmart Grocery customers to pay for same-day deliveries of online purchases on a yearly or monthly basis instead of per order. There's no limit on deliveries for orders of $\$ 30$ or more. Subscriptions cost $\$ 98$ for the annual plan and $\$ 12.95$ for the monthly plan, compared with a $\$ 9.95$ or less 
same-day delivery fee for each order. Similar programs also have Tesco, which includes Free deliveries any day, except same-day ( $£ 2$ charge per order) for $£ 7.99$ per month (Tesco Delivery Saver).

Most often, delivery is carried out on the day of order, sometimes limited by the condition of the order until 12.00. O'Key is delivering the next day, but a collection of products is collected on the day of delivery. Surcharge can be made in the absence of an elevator and the residence of the consumer above the 3rd floor. There are several retailers (Perekrestok, METRO) that provide advanced purchasing options, delivering not only through the partner company of the delivery service Igooods.ru, but also delivering them from the hypermarket and on their own terms. But the amount of the minimum order on the retailers' own websites increases to 1000 rubles. The consumer can check the quality of food products only after the courier leaves. In case of claims, the replacement of goods and refunds are carried out only after an independent examination. Information on the properties of the product and its distinguishing features for functional bread and bakery products is not available in online stores and physical retailers, regardless of the type of online store and country of origin, limited to the minimum mandatory information in the labelling.

Functional food products, including bread and bakery products, are enriched in one or a complex of substances of natural or mineral origin, which ensures the prevention of alimentary-dependent diseases with their regular use. Often the higher cost of such products is offset by their beneficial properties, which consumers should be informed about. A significant amount of information about the distinctive properties of a new functional food product cannot fit in the labelling, but will be easily available on the website of the online store (Figure 3).

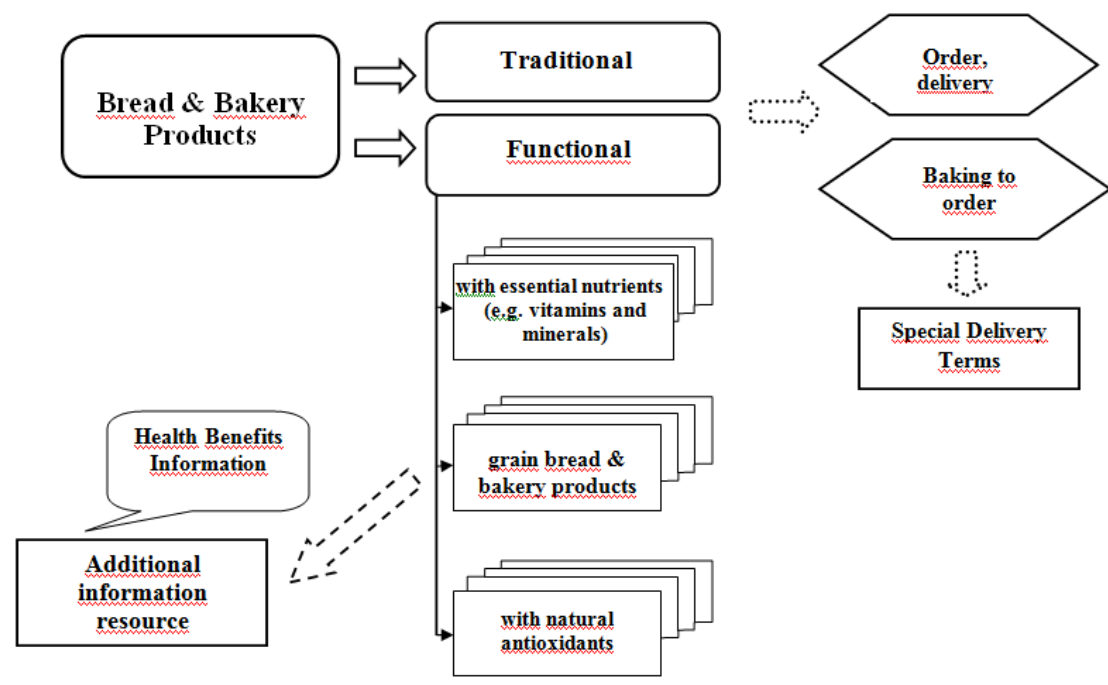

Fig. 3. Opportunities of trading online to promote functional bread and bakery products.

With a clear positioning of a functional food product among a wide variety of assortment of an online store and a specific product group, it will allow the consumer to receive sufficient information. Therefore, in the product group "Bread and bakery products", the subgroup "Functional bread and bakery products" should be allocated, and it contains specific types that exist in modern conditions: with vitamin-mineral complexes; cereal bread and bakery products; with natural antioxidants due to additives from plant ingredients. The use of the latter can lead to an increase in the cost of functional bakery 
products, and consumers can purchase this food product only subject to its high palatability. Baking to order will allow the consumer to guaranteed get a fresh bakery product, try it, and if you like it, then purchase it in the future.

The optional "Baking to order" function takes time to prepare the product selected by the consumer. In this case, you must enter special delivery conditions. Delivery time after order should be calculated taking into account the time for production of the product. Therefore, when ordering bakery products of their own bakeries in hypermarkets, delivery time should be increased to 6 hours, and when ordering products of large bakery enterprises, delivery can be carried out only the next day.

\section{Conclusions}

Food products, including functional foods, are sold in St. Petersburg, Russia, both in retail and online stores on their own sites or partner sites. Currently, only $18 \%$ of consumers surveyed use the Internet service for purchasing food products. Among the reasons for the refusal to use the online service, one can single out the development of the network of retail trade enterprises, the absence of significant differences in the assortment between online stores and retail trade enterprises; lack of confidence in the delivery of quality and fresh products for perishable foodstuffs, the difficulty of returning. In the "Bread and bakery products" product group, functional products are mainly represented by grain bread. In this segment, there is no clear positioning of functional products and information on distinctive features that can attract consumers. A model of the structure of the segment of the website of the online store is proposed, including additional sources about the distinguishing features (health benefits) of functional bakery productsBwith their clear positioning, additional services "baked goods on order", guaranteeing the delivery of fresh products under special delivery terms.

This paper was financially supported by the Ministry of Education and Science of the Russian Federation on the programm to improve the competitiveness of Peter the Great St. Petersburg Polytechnic University (SPbPU) among the world's leading research and education centers in the 2016-2020.

\section{References}

1. D. Grewal, A. L. Roggeveen, J. Nordfält, J. Retail. Consum. Serv. 93(1), 1-6 (2017). doi: $10.1016 /$ j.jretai.2016.12.008

2. M.A. Goreva, Internet marketing, 2, 110-115 (2013).

3. G. Wagner, H. Schramm-Klein, S. Steinmann, Journal of Business Research, 107, 256270 (2020). https://doi.org/10.1016/j.jbusres.2018.10.048

4. G. McLean, K. Osei-Frimpong, Kh. Al-Nabhani, H. Marriott, Journal of Business Research, 106, 139-157 (2020). https://doi.org/10.1016/j.jbusres.2019.08.032

5. G. Festa, M.T. Cuomo, G. Metallo, Journal of Business Research, 101, 477-484 (2019). https://doi.org/10.1016/j.jbusres.2018.12.077

6. J.W. Kang, Y. Namkung, International Journal of Hospitality Management, 78, 189198 (2019). https://doi.org/10.1016/j.ijhm.2018.10.011

7. J. Lin, J. Guo, O. Turel, Sh. Liu, International Journal of Information Management, 102033 (2019). https://www.sciencedirect.com/science/article/pii/S0268401219304979 https://doi.org/10.1016/j.ijinfomgt.2019.11.001 
8. L.P. Nilova, S.M. Malyutenkova, S.A. Chunin, N.V. Naunenko, IOP Conf. Series: Materials Science and Engineering, 497, 012112 (2019). doi:10.1088/1757899X/497/1/012112

9. E. Cristobal-Fransi, Y. Montegut-Salla, B. Ferrer-Rosell, N. Daries, Journal of Rural Studies, 74, 55-66 (2020). doi:10.1016/j.jrurstud.2019.11.011

10. L. Wu, Journal of Retailing and Consumer Services, 49, 253-266 (2019). doi: 10.1016/j.jretconser.2019.04.003

11. Yu.W. Sullivan, D.J. Kim, International Journal of Information Management, 39, 199219, (2018). doi: 10.1016/j.ijinfomgt.2017.12.008

12. Ch.-Ch. Liang, W.-Ya. Liang, T.-L. Tseng, Computer Standards \& Interfaces, 65, 122131 (2019). doi: 10.1016/j.csi.2019.03.002

13. Zh. Liu, Z. Li, International Journal of Information Management, 102059 (2019). https://doi.org/10.1016/j.ijinfomgt.2019.102059

14. A. Krewinkel, S. Sünkler, D. Lewandowski, N. Finck, B. Tolg, L.W. Kroh, G.A. Schreibe, J. Fritsche. Food Control, 61, 204-212 (2016). https://doi.org/10.1016/j.foodcont.2015.09.039

15. X. Ji, H. Yang, J. Wang, R. Li, H. Zhao, J. Xu, Y. Xiao, B. Tang, M. Qian, Food Control, 92, 391-398 (2018). doi: 10.1016/j.foodcont.2018.05.020

16. A. Pinto, A. Mottola, P. Marchetti, A. Savarino, Journal of Food Composition and Analysis, 79, 143-147 (2019). https://doi.org/10.1016/j.jfca.2019.03.018

17. L. P. Nilova, S. M. Malyutenkova, R. A. Ikramov, The International Scientific Journal, 5, 32-37 (2019). doi: 10.34286/1995-4638-2019-68-5-32-37

18. I. Siró, E. Kápolna, B. Kápolna, A. Lugasi, Appetite, 51 (3), 456-467 (2008). https://doi.org/10.1016/j.appet.2008.05.060

19. A. Annunziata, R. Vecchio, Journal of Functional Foods, 3 (3), 223-228 (2011). https://doi.org/10.1016/j.jff.2011.03.011

20. Analytics: sale of food products on-line (world and Russia) (2019). https://rees46.com/blog/index.php/2018/02/16/grocery-market/

21. L. Nilova, S. Malyutenkova, Agronomy Research, 16(2), 1444-1456 (2018). https://doi.org/10.15159/AR.18.055

22. D. Dziki, R. Różyło, U. Gawlik-Dziki, M. Świeca,Trends in Food Science \& Technology, 40 (1), 48-61 (2014). http://dx.doi.org/10.1016/j.tifs.2014.07.010 